\title{
Citizenship literacy for primary schools: An effort for Indonesia's future challenges
}

\author{
M. Wahono* \\ Universitas Negeri Semarang, Semarang, Indonesia \\ Dianasari \\ Universitas Muhammadiyah Cirebon, Cirebon, Indonesia \\ Y. Hidayah \\ Universitas Ahmad Dahlan, Yogyakarta, Indonesia
}

\begin{abstract}
This study aimed to initiate citizenship literacy for elementary schools to discover solutions for Indonesia's future challenges. The method used qualitative methods by using several literature studies as a design. The results of the study showed that citizenship literacy for elementary school was done by using sites of citizenship that were customized to meet the needs of learning at the elementary school level. The understanding of citizenship literacy for elementary school was in line with the goal of Civic Education in the context of Indonesia. Besides, cooperation and efforts of various groups including family, government, community, and school were necessary to achieve the success of citizenship literacy for the elementary school in the future. This study recommends further research on some efforts in utilizing local wealth as an opportunity to release the golden generation in the future.
\end{abstract}

Keywords: citizenship literacy, children, elementary school, the future of Indonesia

\section{INTRODUCTION}

The optimization of literacy movement at an early age becomes an important thing to improve the output quality of education. However, the definition of literacy was not just limited to the ability of reading and writing, but also digital literacy beneficial for welfare (Fajriyah \& Fauziyah, 2018; Rogers, 2011). The emphasis of the literacy movement at an early age was a good time to learn because there existed an opportunity to teach children about concepts (Hidayah et al. 2019).

Concerned the meaning of "literacy," Civic Education as a subject that has been taught since primary school to university as in accordance with the mandate of Article 37 paragraph (1) and (2) of Law Number 20 Year 2003 on National Education System, seeks to popularize citizenship literacy to form citizen in accordance with Pancasila and the Constitution of 1945. The introduction of the citizenship literacy concept in primary school is an attempt to provide a basis for students about the state: Indonesia.

The student learning environment was real-world participatory planning (Oonk et al. 2019). In other words, through citizenship literacy in elementary school, the habituation of thinking about Indonesia will be beneficial in higher education, even when they are working and raising a family. Regardless of age, a worker required the right skills and knowledge to become productive and to assist the organization in achieving strategic objectives (Davies et al. 2017).

${ }^{*}$ Corresponding Author 
At present, education attempts to address global challenges referred to as globalization. Globalization was a spacious social area, hegemonic, and intertwined with social groups on a world scale (de Sousa Santos, 2006). Presently, education is expected to produce individuals who are not only competent academically but to have critical and logical thinking. Therefore, it was beyond the current power configuration problems and tended to shift power (Rizvi, 2007).

Literacy education in primary school can be started by reading habituation. There were many different approaches to teach literacy at the early ages (Hill, 1995). The levels of literacy skills are along with children's ability to receive, process, and respond to any information. A study that examined the effects of early literacy teaching in kindergarten students showed that children who received additional instruction performed significantly better in terms of rhyme, alliteration, knowledge of letters, the relationship of letter and sound, spelling, and combine tasks than children who receive instructions one by one through a tutoring program (Bingham et al. 2010).

Based on a report from the National Early Literacy Panel in 2008, there were at least extensive meta-analyses of 300 studies that showed early literacy measures that correlated with later literacy achievement (Shanahan \& Lonigan, 2010). Thus, the early stages of literacy are fundamental in fostering the critical thinking and logical nature of children.

The previous research that discusses the level of citizenship literacy in elementary school is: a study in Korea for two years on ten fifth and sixth grade students (11-12 years old) that proposed to incorporate intercultural critical citizenship, illustrated those critical skills of citizenship can be developed with the pedagogy of teachers. They could help students to reflect the knowledge and cultural practices that seem natural to them (Huh \& Suh, 2017).

A study on promoting popular media as a pedagogical tool institutionalized within the framework of critical media literacy that refers to values and codes of multiculturalism, found a promoted model of citizenship in students' textbooks in 2003 composed by the Ministry of Education Ontario in Canada. On the contrary, the promotion failed. The curriculum of Ontario media of literacy failed to interrogate social roots of conflict and discrimination (Ferguson, 2011).

An analysis that aimed to bring the theory of intercultural civic education becomes a concern among academics, whereas civic education explained the reasons and concepts involved in intercultural Citizenship Education (Porto et al. 2017). Academically, Walsh et al. (2014) gave evidence to overcome factors outside the school that affect students' learning. By conducting research on 7.948 students from 1999 to 2009, has resulted in students at City Connects presenting a high report score, and get a high score in Arts, Math, and English after giving a supportive intervention for them.

Furthermore, a study that described some of the core aspects of the experience of Omar Dengo Foundation at Costa Rica in the development of Citizenship Education program based on the conception of children as a citizen have produced that the educational program becomes a modeled program designed for elementary and it presented lessons learned from the process of improving initiatives (Fonseca \& Bujanda, 2010).

Based on previous studies, we know that instilling any concept in Citizenship Education has been implemented through many challenges from time to time. The argument makes researchers interested in conducting a study on Citizenship Literacy for Elementary School to prove that students at the elementary school level have a strategic position for citizenship concept instilling. The subject was 8 years old students and 6 years old students that became a mental age predictor of success (Lutzer, 1986).

The previous research has demonstrated the positive impact of doing research on teacher's pedagogy. However, there are a few studies on the challenges and benefits of doing research in Indonesia, the Philippines, and ASEAN regions (Ulla, 2018). Thus, this study formulates a question on "How can citizenship literacy in elementary school deal with facing challenges of Indonesia in the future?"

The position and importance of this study are: it is theoretically useful to add insight into citizenship at the primary school level and it has practically become the basis for similar further studies. This study contributed to scientific development and the resolution of related problems regarding civic education in primary schools. 


\section{METHODS}

This study used qualitative descriptive in terms of literature study as design. Data was collected from various sources such as books, journal articles, and other relevant sources. Knowledge embedded in the value system of individuals was the fundamental basis for explaining how innovation occurs (Bressan, 2004). The researchers compared some data to determine citizenship literacy for elementary schools to answer Indonesia's challenges in the future. Researchers compared several data to determine the nationality of primary schools to respond to Indonesia's challenges in the future. In detail, the stages of implementing library research were: (1) keywords search on Citizenship Literacy for Elementary Schools, (2) search finding the latest books and scientific articles on Citizenship Literacy for Elementary Schools, (3) systematic reading analysis, especially full-text sources on Citizenship Literacy for Elementary Schools, (4) grouping Citizenship Literacy for Elementary Schools to find the core of the problem, (5) determining conclusions and suggestions.

\section{RESULTS AND DISCUSSION}

\subsection{Site of citizenship literacy for elementary school}

The idea of citizenship sites as citizenship literacy sites for elementary school is an effort to exploit these sites to be citizenship literacy for primary school (elementary school). The concept of citizenship site was an initiative at the local level that allows for democratic citizenship practices that could encourage citizen participation in the context of the nation's life (Muwafiq, 2012).

At the elementary school level in Indonesia, citizenship literacy can be started by introducing the state, state's motto, state's principle. Many early literacy interpretations were too narrow and ignore the important role of background knowledge and conceptual development (Neuman, 2010). The introduction in the level of state's structures at the Primary School level in Indonesia is enabled to prepare students' social and emotional development, cognition aspect, language, and citizenship literacy on a number of important aspects that are compulsory to be possessed by students as Indonesian.

The urgency of children's preparation as Indonesian is in line with the objectives of National Education stated in Law Number 20 Year 2003 which ends with the assertion that each democratic citizen need to “...become a democratic and responsible citizen." The development of children's citizenship literacy concerns existing patterns of education.

The site of citizenship as citizenship literacy for elementary school expects the existence of practical improvement of citizenship in maintaining the existence of citizens in democratic countries. In America, there was an idea that the current American schools' crisis is a symptom of a wider crisis in the meaning and practice of democracy (Giroux, 1992). In Indonesia, the site of citizenship as citizenship literacy for elementary school refers to the introduction of national identity maintenance. A study that examined how character education and multicultural values education can contribute to Indonesia in 2045 (100 years old of Indonesia), produced that the form of education should not be limited to conceptualization aspect, but to understanding aspect of personality traits and considering globalization aspect (Malihah, 2015).

For Indonesian, national identity is a manifestation of national identity in the future. The elementary school as formal education in Indonesia has an opportunity to take a part in nation intelligence development as stated in "Unity in Diversity" or Bhinneka Tunggal Ika at the elementary school level. Citizenship education should be reformed to reflect home cultures and languages of students from various groups, and this action could help individuals to achieve structural equality (Banks, 2008).

The pattern of recognition on citizenship sites as citizenship literacy for Elementary School is to emphasize the fact of Indonesia as a great nation with a wealth of language differences, religion, 
and culture as Indonesian's national identity. Citizenship literacy at the elementary school level is expected to have a positive impact on the introduction of the statehood (Indonesia) concept on students.

\subsection{Citizenship literacy for elementary school and future challenges of Indonesia}

The concept of citizenship literacy for elementary school also becomes an attempt to prepare children to have the ability to learn citizenship. The movement of critical thinking was expected to benefit from conceptualizing the lesson material in a development framework (Kuhn, 1999). Concerning the challenges of Indonesia in the future, the 21 st-century curriculum is to consider the use of information technology and the emphasis on graduates that are ready to work. Besides, discipline forced the 21 st-century curriculum to prepare graduates to learn continuously (Gosper \& Ifenthaler, 2014). There were at least seven challenges for Indonesia in the future that could be formulated, i.e. a demographic bonus, stunting, qualified early childhood education, dropout rates, unemployment, disruption of technology, and regional autonomy (Harususilo, 2019). In the 21st century, the pattern of education is expected to increase. There was a suggestion that cultural awareness and background knowledge of students could eliminate competence hamper students' learning (Wang, 2018).

To respond to the challenge, the problem of attitude and way of communication between teacher and student has become a concern. A study that examined the role of social support and adjustment in predicting academic stress among first-year students at Syiah Kuala University revealed that the two aspects of social support and customization significantly predicted academic pressure (Hamzah $\&$ Marhamah, 2015). The present education is required to be able to adapt with times, especially in the era of the industrial revolution.

Citizenship literacy for elementary school and Indonesia's future challenge is an effort to prepare superior human resources in the future based on Pancasila and the Constitution of 1945. The study on education was distracted by a skeptic that doubted its quality and relevance (Ball \& Forzani, 2007). For elementary schools, understanding aspects of Indonesia is a solution to connect information with other useful information of Indonesia.

To reconsider the challenge of Indonesia in the near future, citizenship literacy for elementary school occurs as a perspective in finding out solutions on civic knowledge degradation in Indonesia. The attitude of lateral preference on children was not dimensional (Gudmundsson, 1993). It is crucial to understand the position of education in Indonesia to respond to the symptoms of civic knowledge degradation. In the last decade, the important struggles on the production of knowledge had occurred in history, social sciences, and education (Popkewitz, 1997).

The composition of an educational model that can export competence of learners is used to formulate competence in the 21 st century. The broad generalization in all aspects of human psychology concerns the major differences of individuals. On the other hand, the strength, sturdy, and well-established human capabilities were not utilized well in school (Suppes et al. 1998). The presence of learning media in the industrial revolution is appropriately utilized to support the learning process.

Citizenship literacy for elementary school and Indonesia's future challenge is formulated to infiltrate into various fields of learners. The distribution of education output was focused on soft skills (Hariyanto et al. 2019). Any change runs continuously. Thereby, citizenship literacy for the elementary school in Indonesia is in an offer to address challenges of the future.

\section{CONCLUSIONS}

Citizenship literacy for elementary school was to confirm the purpose of Civic Education in the context of Indonesia. Cooperation of family, government, community, and school was expected for the success of citizenship literacy in elementary school. Citizenship literacy for elementary school was a basis for students to recognize civic activity. Therefore, to support the realization of a smart 
and good citizen, citizenship literacy needs to be popularized by academics of Civic Education in elementary school. Future studies are necessary to analyze local wealth as an opportunity to release the golden generation in the future.

\section{REFERENCES}

Ball, D.L. \& Forzani, F.M. 2007. Wallace Foundation Distinguished Lecture-What makes education research "educational"? Educational Researcher 36(9): 529-540.

Banks, J.A. 2008. Diversity, group identity, and Citizenship Education in a global age. Educational Researcher 37(3): 129-139.

Bingham, G. E. et al. 2010. Systematic and engaging early literacy: Examining the effects of paraeducator implemented early literacy instruction. Communication Disorders Quarterly 32(1): 38-49.

Bressan, B. 2004. A study of the research and development benefits to society resulting from an International Research Centre. Helsinki: Faculty of Science of the University of Helsinki.

Davies, E. et al. 2017. Learning and training for older workers. In H. Karen et al. (eds), Managing the ageing workforce in the East and the West: 185-206. United Kingdom: Emerald Publishing Limited.

de Sousa Santos, B. 2006. Globalizations. Theory, Culture \& Society 23(2-3), 393-399.

Fajriyah, L. \& Fauziyah, P. 2018. The role of ICT to develop early literacy of children in era digital. In R. Windiarti (ed.), Semarang early childhood research and education talks (SECRET 2018): 112-116; Proc. intern. conf., Semarang, 8-9 August 2018. Paris: Atlantis Press.

Ferguson, S. 2011. Classroom contradictions: Popular media in Ontario schools' literacy and citizenship education policies. Education, Citizenship and Social Justice 6(2): 137-151.

Fonseca, C. \& Bujanda, M.E. 2010. Promoting children's capacities for active and deliberative citizenship with digital technologies: The CADE Project in Costa Rica. The ANNALS of the American Academy of Political and Social Science 633(1): 243-262.

Giroux, H. A. 1992. Educational leadership and the crisis of democratic government. Educational Researcher 21(4): 4-11.

Gosper, M. \& Ifenthaler, D. 2014. Curriculum models for the 21st Century: Using learning technologies in higher education. Netherlands: Springer.

Gudmundsson, E. 1993. Lateral Preference of Preschool and Primary School Children. Perceptual and Motor Skills 77(3): 819-828.

Hamzah, H. \& Marhamah, F. 2015. Social support, adjustment and academic stress among first year students in Syiah Kuala University. In S.I.A. Dwiningrum (eds), 2nd international conference on current issues in education: 447-450; Proc. intern. conf., Yogyakarta, 25-26 August 2015. Yogyakarta: Yogyakarta State University.

Hariyanto, H. et al. 2019. The analysis of student's verbal communication skills by gender in the middle school in South Tangerang. In A. Suparmi \& D.A. Nugraha (eds), International conference on science and applied science (ICSAS): 020064-1-020064-6; AIP conf. proc., Surakarta, 20 July 2019. Surakarta: AIP Publishing.

Harususilo, Y.E. 2019. 7 tantangan pendidikan indonesia, dari stunting sampai pengangguran. Retrieved from kompas.com.

Hidayah, Y. et al. 2019. Transformasi kearifan lokal jawa dalam pendidikan karakter sekolah dasar. AULADUNA: Jurnal Pendidikan Dasar Islam 6(1): 50-61.

Hill, S. 1995. Early literacy and diversity. Australasian Journal of Early Childhood 20(1): 23-27.

Huh, S. \& Suh, Y.M. 2017. Preparing elementary readers to be critical intercultural citizens through literacy education. Language Teaching Research 22(5): 532-551.

Kuhn, D. 1999. A developmental model of critical thinking. Educational Researcher 28(2): 16-46.

Lutzer, V.D.F. 1986. Perceptual learning by educable mentally retarded, average, and gifted children of primary school age. Perceptual and Motor Skills 62(3): 959-966.

Malihah, E. 2015. An ideal Indonesian in an increasingly competitive world: Personal character and values required to realize a projected 2045 'Golden Indonesia'. Citizenship, Social and Economic Education 14(2): $148-156$.

Muwafiq, A. 2012. Pesantren sebagai situs kewarganegaraan dan pembentukan budaya kewargaan di Madura. Jurnal Civics 14(2): 183-195.

Neuman, S.B. 2010. Lessons from my mother: Reflections on the National Early Literacy Panel Report. Educational Researcher 39(4): 301-304. 
Oonk, C. et al. 2019. Educating boundary crossing planners: Evidence for student learning in the multistakeholder regional learning environment. Journal of Planning Education and Research 39(3): 360-373.

Popkewitz, T. S. 1997. A changing terrain of knowledge and power: A social epistemology of educational research. Educational Researcher 26(9): 18-29.

Porto, M. et al. 2017. Intercultural citizenship in the (foreign) language classroom. Language Teaching Research 22(5): 484-498.

Rizvi, F. 2007. Postcolonialism and globalization in education. Cultural Studies $\leftrightarrow$ Critical Methodologies 7(3): 256-263.

Rogers, T. July 2011. Literacy, leadership and marginalized groups. In the 7th Pan African Reading for all Conference, Gaborone: University of Botswana.

Shanahan, T. \& Lonigan, C. J. 2010. The national early literacy panel: A summary of the process and the report. Educational Researcher 39(4): 279-285.

Suppes, P. et al. 1998. "The vision thing": Educational research and AERA in the 21st century - Part 5: A vision for educational research and AERA in the 21st Century. Educational Researcher 27(9): 33-35.

Ulla, M.B. 2018. Benefits and challenges of doing research: Experiences from Philippine public-school teachers. Issues in Educational Research 28(3): 797-810.

Walsh, M. E. et al. 2014. A new model for student support in high-poverty urban elementary schools: Effects on elementary and middle school academic outcomes. American Educational Research Journal 51(4): 704-737.

Wang, G. 2018. On the strategies of enhancing students' cultural awareness in College English Teaching. English Language Teaching Canadian Center of Science and Education 11(12): 116-120. 